\title{
A Frame-Semantic of the Verb 'Fall down' and the Verbs Related to the Cause of Fall down in Sundanese Language
}

\author{
Aan Ramadhansyah Rahayu \\ Department of Linguistics, Universitas Padjadjaran \\ Subang, Indonesia \\ E-mail: arrahayu@gmail.com
}

\begin{abstract}
This study shows how the theory of Frame Semantic developed by Fillmore \& Baker (2010) can help to describe and analyze different kinds of frame elements of Sundanese verb evoking the 'fall down' frame. Many ways can be found in Sundanese verbs for evoking 'fall down' frame due to their variation in frame elements. This study applied a descriptive qualitative method, and the data are ten Sundanese lexis that evokes the frame 'fall down' collected as the unit of analysis. The main findings show that Sundanese verb, which evokes the 'fall down' have different frame elements. These differences of frame elements, including the part of the body, which fall down, the cause of falling and the direction of falling. Therefore, the detail frame elements in describing how the verb in Sundanese evokes the frame 'fall down' enrich the Sundanese vocabularies, which evoke the 'fall down' frame.
\end{abstract}

Keywords: frame, frame elements, frame semantic

\section{INTRODUCTION}

In Sundanese language, the verb 'fall down' can be explained in many kinds of verbs such as titajong, tiserelue, tigebrus, tikusruk and many more. Due to these variations of using the verb 'fall down' in Sundanese language, the Sundanese learners sometimes do not know which 'verb' that evoke the frame 'fall down' that they refer to, or whether they have used the right words to describe which 'fall down' they mean. In an attempt to reduce this issue, the present frame-based study of the Sundanese verb evoking the verb 'fall down' demonstrates how using Frame Semantics theory (Fillmore\& Baker 2010) helps clarify the different uses of those Sundanese verbs.

In an attempt to reduce this problem, the current frame-based analysis of the Sundanese verb evoking the verb 'fall down' shows how the use of the Frame Semantics Theory (Fillmore\&Baker 2010) helps explain the different use of the Sundanese verbs.Frames are cognitive structures that commonlydefine the understanding linguistic formprocess as part of language knowledge (Fillmore \& Baker 2010).Besides, Johnson, et al (2003) also argues that a frame is an abstract conceptual schema of an event, state 
of affairs, or circumstance. It is an essential element that structures the way people understand and remember experiences; and how they make sense of the way they perceive such experiences. Semantic frames evoke internal knowledge, and this knowledge is not only associated with words but also with cultural values. In Frame Semantic, words are defined concerning their background frame and not just about other words.

\section{THEORETICAL FRAMEWORK}

\section{Semantic}

Semantic is used to find the relation between linguistic forms and their meanings. Thus Semantic analysis deal with how features of meaning are attached in features of linguistic form. However, frame semantic offers a different way of seeing the meaning of a word. Fillmore \& Baker (2010) argued that the meaning of a word cannot be treated in isolation, but are rooted in a larger body of knowledge. It is said that the semantic frame providesa background of belief and experiences necessary to interpret the lexical meaning of the word; yet, having all the knowledge access relating to that word is critical.

\section{Frame Semantic}

A semantic frame is therefore defined as a coherent structure of related concepts: without knowledge of all of them, we do not have complete knowledge of one of them. For example, children are familiar with experiences of pain before they face the various linguistic means of talking about them. These include utterances expressing a current experience of pain (ouch!). The clause associates pain with the body, parts or whole (my foot hurts, my toothaches), clauses associating pain with particular causes of pain ( the injection won't hurt, these shoes hurt, you're hurting me), and ultimately an abstraction designating the quality of such experiences (pain is a powerful motivating force). (Fillmore and Baker, 2010)

Conversely, the dictionary definition of the words like pain, hurt, ache and ouch cannot explain this concept, but only give pointers to the kinds of experiences in which the learner is already familiar. 
In other words, Frame Semantic is the study of how linguistic forms evoke or activate frame knowledge, and how the frames that have been activated be integrated into an understanding of the passage that contains these forms. Therefore, the effort in understanding the meaning involves the non-linguistic information which is integrated into the process of people gain their knowledge through experience to understand a word, a clause, a sentence, or a group of sentences, which may evoke a frame or a group frames.

\section{Frame Elements}

Each semantic frame consists of two typesof Frame Elements (FE): core element, which isspecific to the frame in question, and non-core elements, which may appear as part of that frame but may also occur in other frames (Petruck 1996). Core elements are essential concepts to the understanding of a Lexical Unit (LU) and its frame, while noncore elements provide additional information to a given frame but are not always critical to the understanding and interpretation of meaning (Fillmore \& Baker 2010).

Fillmore \& Baker (2010) give an example of how to understand the wordalimonyin a sentence 'Leo has missed three successive alimony payments'. To understand alimony requires to understand the worddivorce and the kinds of contracts that can be entered athe time of a divorce. To understand divorce requires knowing about marriage and its commitments; to understand missing three consecutive payments requires the knowledge of the kinds of periodic commitments undertaken with an alimony agreement, and to know that missing a payment is a failure to honour such a commitment. Describing the payments as having been missed, rather than using a neutral expression like did not make (the payments), reveals an evaluation that this is a failure on Leo's part. All of this comes with knowledge of meanings of the associated words. In this case,it is centeredon the concept of alimony. The example of analysis above is used to analyze and describe the Sundanese verbs 'fall down' as an attempt to give a further understanding how to use the Sundanese verbs that evoke the frame 'fall down'

Therefore, using the theory of Frame Semantics (Fillmore \& Baker 2010) as a framework, the writeranalyzes the frame elements and lexical unit of individual words in Sundanese verbs evoking the 'fall down' frame. The writers argue that this theory 
helps to describe how Sundanese verbs 'fall down' evoke different meaning and experience. The research questions for this study are:

- What is the Frame Semantic Elements of Sundanese verbs "fall down"?

- What makes the Sundanese verbs 'fall down' evoke different frame?

Hopefully, this research can give a fruitful knowledge in understanding and using Sundanese verbs 'fall down' and help the readers to see the differences regarding the use of those verbs.

\section{METHOD}

This research applied the descriptive qualitative method. This research used the data in the form of Sundanese lexis that evokes the frame 'fall down'. There are ten Sundanese verbs which evoke the frame 'fall down' collected as the unit of analysis. Those verbs were taken from Sundanese Dictionary. After collecting the data, the analysis was conducted to answer the research questions. The following steps were conducted to analyze the data:

1. the verbs were listed into a table

2. the verbs were written in a sentence

3. the frame semanticswere identified from the sentence

4. the frame semantics were listed into a table

5. the elements that evoke different frames were Sundanese verbs 'fall down' were analyzed based on the theory of Frame Semantics Fillmore and Baker (2010)

After all the steps of analysis wereconducted, the conclusion was made based on the finding of the research.

\section{RESULT AND DISCUSSION}

\section{Result}

There are 10 data of frame semantic related to the variation of verbs "fall down" in Sundanese language. They are presented in the following table. 
Table 1 List of frame elements in Sundanese Verb evoke the frame 'fall down'

\begin{tabular}{|l|l|l|}
\hline No. & Frame Semantic & Frame elements \\
\hline 1. & tisoledat & Slippery surface; rainy; walk \\
\hline 2. & tigeledug & Slippery surface; floor; head; \\
\hline 3. & tikusruk & ricefield; hurried; frontside \\
\hline 4. & titajong & rock; careless; daydreaming; kick \\
\hline 5. & Tijalikeuh & foot; high-heels shoes \\
\hline 6. & Tigurawil & down the tree; brittle branches; hanging \\
\hline 7. & Tikosewad & step; small bridge; imbalance \\
\hline 8. & tigedebrus & walk; hole; muddy \\
\hline 9. & tijengkang & stand up; sit down; fall; backwards \\
\hline 10. & Tikudawet & step; long skirt/clothes \\
\hline
\end{tabular}

The table above shows the variation of verbs 'fall down' in Sundanese that evokes different meaning. Those difference meaning could be seen from the different cause of falling, such as falling due to walking in slippery surface (tisoledat); falling due to carelessly hit rock while walking (titajong); falling into a hole when walking in the muddy place (tigedebrus); stumbling due to put on high-heels shoes (tijalikeuh); stumbling when down from trees due to step on brittle branches (tigurawil); falling due to imbalance when stepping on a small bridge (tikosewad); and falling due to step on long skirt/cloth (tikudawet).

The other kinds of verbs 'fall down' could be differentiated according to part of the body that got hurt, such as 'tigeledug' when the 'head' hit the floor during fall; 'tigurawil' when the whole body hang on the tree. Another verb could be differentiated from the direction of falling, such as 'tikusruk' to tell stumbling into frontside and 'tijengkang' to tell falling into backwards. Therefore, according to its frame elements, the variation of the Sundanese verb that evokes the frame 'fall down' can be differentiated into: the cause of falling, the part of body involved in falling, and the direction of falling.

\section{Discussion}

\section{Data 1: Tisoledat}

\begin{tabular}{|l|l|l|}
\hline Sundanese & Tisoledat & Ali tisoledat di pipir anu leueur sanggeus tadi hujan gede. \\
\hline English & Slipped & Ali slipped at the slippery yard after heavy rain. \\
\hline
\end{tabular}


The verb 'tisoledat' comes from the root word 'soledat' and prefix 'ti'. According to Sundanese dictionary, 'soledat' means slipped and prefix 'ti' shows active subject focus in which 'Ali' is the focus of this sentence. Prefix 'ti' shows that the activity is unintentional. To understand the meaning of 'tisoledat' requires the frame elements 'leueur' (slippery) and 'hujan' (rain) as the cause of the falling down. The word 'leueur' and 'hujan' areas the main lexical units that followthe verb 'tisoledat' in which 'leueur' is an adjective, and 'hujan' is a noun. Therefore the pattern of the verb 'tisoledat' is followed by two frames semantic: leueur (slippery) that explains the condition of the surrounding place when Ali is walking, and hujan (rain/water) that explains the cause of slippery. It is also followed by two lexical units adjective (slippery) describing how is the place 'pipir' (yard), and noun (rain/water) informing the cause of the place being slippery. From the sentence above, it can be understood that the word 'soledat' is used to describe falling, which causes by slippery condition surrounding the place where the subject is walking.

\section{Data 2: Tigeledug}

\begin{tabular}{|l|l|l|}
\hline Sundanese & Tigeledug & Bagus tigeledug kanu tehel lantaran leueur. \\
\hline English & Stumble & Bagus stumbled in the slippery floor. \\
\hline
\end{tabular}

The word 'tigeledug' is an active verb, which comes from affix ' $t i$ ' and the root 'geledug'. Based on Sundanese dictionary 'geledug' means stumble due to the head hits the floor, and affix 'ti' shows the subject active which 'Bagus' is the focus of the sentences. To understand the meaning of 'tigeledug' needs the frame element 'téhel' (floor) and 'leueur' (slippery) as the cause of falling down. The word 'téhel' and 'leueur' arethe main lexical unitsfollowing verb 'tigeledug', in which 'téhel' is a noun and 'leueur' is an adjective. In this sentence, the verb 'tigeledug' is followed by two frame semantics: 'téhel' (floor) explains the placewhereBagus stumbled and got the head hit into it, next 'leueur' (slippery) explains the cause of the stumble. It is also followed by two lexical unit noun (floor) informing the place of the hit, and adjective (slippery) describing the cause of the place that makesBagus fall down. From the sentence above, itcan be understood that the word 'geledug' is used to describe falling down, which is caused by the slippery condition and make the subject got hit in the head. 


\section{Data 3: Tikusruk}

\begin{tabular}{|l|l|l|}
\hline Sundanese & Tikusruk & $\begin{array}{l}\text { Kabayan tikusruk ka sawah lantaran leumpangna buru- } \\
\text { buru. }\end{array}$ \\
\hline English & Fall headfirst & Kabayan fell to the fields because he ran hurriedly. \\
\hline
\end{tabular}

The word 'tikusruk' is an active verb which comes from affix 'ti' and the root 'kusruk'. Based on Sundanese dictionary 'kusruk' means fall down (towards the front side) and affix 'ti' shows subject active which 'Kabayan' is the focus of the sentences. To get the meaning of 'tikusruk', needs the frame element 'sawah' (ricefield) and 'buruburu' (hurriedly) as the cause of falling down. The word 'sawah' and 'buru-buru' are the main lexical units follow theverb 'tigeledug', 'sawah' is a noun and 'buru-buru' is an adjective. In this sentence the verb 'tikusruk' is followed by two frames semantics: 'sawah' (ricefield) shows the place condition when Kabayanfelldown, and 'buru-buru' (hastily/in a hurry) explains whatcausesKabayan to fall down. It is also followed by two lexical unit noun (ricefield) informing the place of the fall and adjective (in a hurry) describing the conditions when Kabayan is running. From the sentence above, it can be concluded that the word 'kusruk' is used to explain falling down, which causes hurriedly condition and make the subject fall down (towards the front side).

\section{Data 4: Titajong}

\begin{tabular}{|l|l|l|}
\hline Sundanese & Titajong & $\begin{array}{l}\text { Dadang titajong kanu batu lantaran lamun leumpang sok bari } \\
\text { ngalamun. }\end{array}$ \\
\hline English & Stumble & $\begin{array}{l}\text { Dadang stumbled over a rock because he was daydreaming } \\
\text { while walking. }\end{array}$ \\
\hline
\end{tabular}

The verb 'titajong' is an active verb that comes from the root 'tajong' and affix 'ti'. According to Sundanese dictionary, 'tajong' means kick and affix 'ti' shows subject active that Dadang is the focus of the sentence. To know and understand the meaning of 'titajong' there should be frame element 'batu' (rock) and 'ngalamun' (daydreaming) as the cause of the stumble. In this part the word 'batu' and 'ngalamun' are the main lexical unitsfor the verb 'titajong' that 'batu' and 'ngalamun' are the nouns of the sentence. In this sentence, the verb 'titajong' followed by three lexical units. First, noun (rock) explains the thing Dadang hits, nextverb (daydreaming) describes the reason Dadang got stumble, and verb (walking) explains the activity he was doing before 
falling down. According to the explanation above, it can be concluded that the verb 'titajongis used to explain a situation where the subject stumbled (kicked something accidentally) because he ignored the road while he was walking.

\section{Data 5: Tijalikeuh}

\begin{tabular}{|l|l|l|}
\hline Sundanese & Tijalikeuh & $\begin{array}{l}\text { Kokom sukuna tijalikeuh lantaran nyobaan sapatu hak } \\
\text { tinggi. }\end{array}$ \\
\hline English & Sprain & Kokom's leg sprained from trying high heels. \\
\hline
\end{tabular}

In this sentence, the word 'tijalikeuh' is an active verb that comes from the root 'jalikeuh' and affix 'ti'. According to the Sundanese dictionary, 'jalikeuh' is a sprain and affix 'ti' shows subject active that Kokom is the focus of the sentence. To know and understand the meaning of 'tijalikeuh' there should be frame element 'suku' (foot) and 'sapatu' (shoes/high heels) as the cause of the sprain. In this part, the word 'suku' and 'sapatu' are the main lexical units following the verb 'tijalikeuh' that 'suku' and 'sapatu' are both nouns of the sentence. In this sentence the verb 'tijalikeuh' is followed by two lexical units: noun (foot) explainspart of the bodyKokom got hurt,andnoun (shoes/high heels) describe the thing caused Kokom got a sprain. According to the explanation above, it can be understood that the verb 'tijalikeuh' is used to explain the situation where the subject is careless when walking and causes sprains to swell.

\section{Data 6: Tigurawil}

\begin{tabular}{|l|l|l|}
\hline Sundanese & Tigurawil & $\begin{array}{l}\text { Abdul tigurawil pas turun dina tangkal jambu anu } \\
\text { dahanna rapuh. }\end{array}$ \\
\hline English & Fall hanging & $\begin{array}{l}\text { Abdul fell down when he down from the guava tree } \\
\text { whose branches were brittle. }\end{array}$ \\
\hline
\end{tabular}

The verb 'tigurawil' is an active verb that comes from the root 'gurawil' and affix 'ti'. According to Sundanese dictionary, 'gurawil' is fall hanging and affix 'ti' shows subject active that Abdul is the focus of the sentence. To know and understand the meaning of 'tigurawil' there should be frame element 'tangkal' (tree) and 'dahanrapuh' (brittle branches) as the cause of the fall. In this part, the words 'tangkal'and 'dahanrapuh' are the main lexical units which following verb 'tigurawil', and then 'tangkal' and 'dahanrapuh' are both the nouns of the sentence. In this sentence, the verb 'tigurawil' is followed by two lexical unit noun (tree) explains the place where 
Abdul fell, and noun (brittle branches) describe the reason why Abdulfall hanging. According to the explanation above, it can be concluded that the verb 'gurawil' is used to explain the situation where the subject down from a tree but the trampled branches are brittle causing fall hanging.

\section{Data 7: Tikosewad}

\begin{tabular}{|l|l|l|}
\hline Sundanese & tikosewad & $\begin{array}{l}\text { Kuring tikoswead gara-gara limbung pas mentas di } \\
\text { jambatan bambu. }\end{array}$ \\
\hline English & slipped & $\begin{array}{l}\text { I slipped because of imbalance when crossing bamboo } \\
\text { bridge. }\end{array}$ \\
\hline
\end{tabular}

The verb 'tikosewad' comes from the root word 'kosewad' and prefix 'ti'. According to Sundanese dictionary, 'kosewad' means slipped and prefix 'ti' shows active subject focus in which 'Kuring' is the focus of this sentence. Prefix 'ti' shows that the activity is unintentional. To understand the meaning of 'tikosewad' requires the frame elements 'limbung' (imbalance) and 'mentas' (crossing) as the cause of the falling down. The word 'imbalance' and 'crossing' arethe main lexical units following the verb 'tikosewad'. The word 'imbalance' is an adjective, and 'crossing' is a verb. Therefore the pattern of the verb 'tikosewad' followed by two frames semantic: 'limbung' (imbalance) explained the condition of the subject when he was crossing, and 'mentas' (crossing) explains the activity of the subject before he falls down. It is also followed by one lexical units 'jambatanbambu' (bamboo bridge) describing the place where falling down begins. From the sentence above, it can be understood that the word 'tikosewad' is used to describe falling down, which causes by imbalance condition when someone was crossing the small bridge.

\section{Data 8: Tigebrus}

\begin{tabular}{|l|l|l|}
\hline Sundanese & Tigebrus & Elli tigebrus kana liangleutak pas leumpang sisi gawir. \\
\hline English & Fall & $\begin{array}{l}\text { Elli was falling into muddy hole when he was walking near } \\
\text { the bank. }\end{array}$ \\
\hline
\end{tabular}

The verb 'tigebrus' comes from the root word 'gebrus' and prefix 'ti'. According to the Sundanese dictionary, 'gebrus' means fall down and prefix 'ti' shows subject active focus in which 'Ali' is the focus of this sentence. Prefix 'ti' shows that 
the activity is unintentional. To understand the meaning of 'tigebrus' requires the frame elements 'lobang' (hole) and 'leumpang' (walk) as the cause of the falling down. The word 'lobang' and 'leumpang' are as the main lexical units follow the verb ' tigebrus' in which 'lobang' is a noun and 'leumpang' is a verb. Therefore the pattern of the verb 'tigebrus' followed by two frames semantic: 'lobang' (hole) that explains the cause of falling, and 'leumpang' (walking) that explains the activity before falling down. It is also followed by two lexical units adjective (muddy) describing how the hole, and noun (gawir) is informing the place. From the sentence above, it can be understood that the word 'tikosewad' is used to describe falling down caused by stepping into a wet hole.

\section{Data 9: Tijengkang}

\begin{tabular}{|l|l|l|}
\hline Sundanese & Tijengkang & Keur nangtung dina bangku pek teh tijengkang katukang \\
\hline English & Fall backward & I was sitting on the bench when I fell down. \\
\hline
\end{tabular}

The verb 'tijengkang' comes from the root word 'jengkang' and prefix 'ti'. According to the Sundanese dictionary, 'jengkang' means fall backward and prefix 'ti' shows subject active focus in which 'Ali' is the focus of this sentence. Prefix 'ti' shows that the activity is unintentional. To understand the meaning of 'tijengkang' requires the frame elements 'nangtung' (stand up) and 'katukang' (backward). These words are as the main lexical units following the verb 'tijengkang' in which 'nangtung' is a verb and 'katukang' is a preposition. Therefore the pattern of the verb 'tijengkang' is followed by two frames semantic: nangtung (stand up) that explains the activity before falling down, and katukang (backward) that explains the direction of falling. From the sentence above, it can be understood that the word 'tijengkang' is used to describe falling down to backwards.

\section{Data 10: Tikudawet}

\begin{tabular}{|l|l|l|}
\hline Sundanese & tikudawet & $\begin{array}{l}\text { Erna sukuna tikudawet lantaran nincak rok anu } \\
\text { kapanjangan. }\end{array}$ \\
\hline English & stumble & Erna stumbled because she stepped on the long skirt. \\
\hline
\end{tabular}

The verb 'tikudawet' comes from the root word 'kudawet' and prefix 'ti'. To understand the meaning of 'tikudawet' requires the frame elements 'nincak' (step), 'rok' 
(skirt) and 'kapanjangan' (too long) as the cause of stumbling, and 'suku' (foot) as the part of the body that caused falling. Therefore, this verb followed by three main lexical units: adjective (long) describing how is the skirt looks like; noun (skirt) something she wears, and verb (stepped) informing the act the lead to stumble. From the sentence above, it can be understood that the word 'tikudawet' is used to describe stumbling, which causes by stepping into a long skirt/clothes.

\section{CONCLUSION}

The analysis shows that the Sundanese verbs of 'fall down', and verbs that related to the cause of fall down have different frame elements, these elements allow Sundanese verbs vary their vocabulary towards the verbs 'fall down'. To conclude, these elements can be categorized into which of part of the body that falls down, the cause of falling, and the direction of falling. These detail frame elements in describing how the verb in Sundaneseevoked the frame 'fall down' have enriched Sundanese vocabularies.

\section{REFERENCES}

Green, V. E. (2006). Cognitive Linguistics: An Introduction. Edinburg: Edinburg University Press.

Ryan Joseph Dux, B. (2011). A Frame Semantic Analysis of Five English Verbs Evoking the Theft Frame. Austin: University of Texas .

Velasquez, P. R. (2016). The Frame Semantic of the Verbs Tocar and Touch across Spanis and English. San Fransisco: San Fransisco State University.

Fillmore, C.J. and M. Baker. 2010. A Frames Approach to Semantic Analysis. In B. Heine and H. Narrog, The Oxford Book of Linguistic Analysis. Oxford University Press: Oxford.

Johnson, C., M. Petruck, C. Baker, M. Ellsworth, J. Ruppenhofer\& C. Fillmore (2003). FrameNet: Theory and Practice. Technical Report. Berkeley: International Computer Science Institute.

Petruck, M. (1996). Frame Semantics. In J-O Östman, J. Bommaert\& C. Bulcaen (Eds), Handbook of Pragmatics (pp. 1-13). Amsterdam/Philadelphia: Benjamins,

Fillmore, C. \& C. Baker (2009). A Frame approach to Semantic Analysis. International Journal of Lexicography 15(2), 313-339. 
Rosidi, A. (2009). Ngalanglang Kasusastran Sunda. Bandung: Kiblat BukuUtama.

\section{Online Reference:}

kamus-sunda.com

https://thegorbalsla.com/bahasa-sunda/

https://www.kamusdaerah.com 